\title{
"Inside Doesn't Matter": Consumerism's Serial Annihilation of Women and the Self in American Psycho
}

\author{
Reagan Ross
}

\begin{abstract}
That...consumption is no longer restricted to the necessities but, on the contrary, mainly concentrates on the superfluities of life...harbors the grave danger that eventually no object of the world will be safe from consumption and annihilation
\end{abstract} through consumption.

- (Arendt, 1958: 133)

Perhaps no film more radically reveals the "serial killer" (cannibalistic) nature of consumerism than American Psycho (2000, Mary Harron). The implications of this disturbing "reality" are cataclysmically far reaching: The end of the world may not come from some tangible material catastrophe (at least insofar as it isn't a corollary of this dehumanization process); rather, more insidiously, it may come via a psychological de-humanization process whereby we literally lose our humanity from the inside out. To understand this development, the film didactically reveals an allconsuming consumption fixation that begins with a food fetish but then is extended to the consumption of women in particular, Others in general, and, most disturbingly - and informing the first two - the "self."

\section{The Political Didactic}

Before I discuss this film, I want to defend the importance of the popular political film (and I would strongly argue that American Psycho is one of the most radical political films ever to come out of Hollywood as I will show in this paper). Indeed, I would argue that the progressive (and subversive) potential of popular cinema in general is substantial. I have argued elsewhere that "popular" films in particular are important as a first step towards breaking free of the commodified and reified chains that keep mass audiences in place.[1] One cannot drag people kicking and screaming into the de-reified air of engagement with the dominant social order; rather, one must do so through a series of steps, the first step being that which they can most relate to, the "popular."

More particularly, the oppositional possibilities of popular cinema reside in what I have called the "political didactic." In present times, the neglected notion of the didactic in aesthetics has been generally seen as a devaluing of art. However, in the postmodern moment, when the norm is the opposite of the didactic - the decentered (displaced, fragmented) and reified subject - the didactic potentially grounds the subject back to a more coalesced perspective of the current moment.

Fredric Jameson has suggested something similar in his work. He has said that we need an aesthetic that allows for "the reinvention of possibilities of cognition and perception [and] that allow social phenomena once again to become transparent, as moments of the struggle between classes" (1977: 212). Jameson has come back to this need for "transparency" repeatedly in his work on the postmodern. Indeed, in his influential concept "cognitive mapping," Jameson posits a kind of aesthetic application with a "deeply pedagogical function [that] teaches us something about what would be involved in positioning ourselves in the world" (Wegner, 2009: 167)." While I do not suggest that 
"popular cinema" can do this, I do suggest that popular cinema can serve a critical function in its didactic mode: as a first step to a break from a reified and commodified existence.

I will also argue that while it is true that popular, mainstream films mostly only offer us the symptoms of a commodifying and reifying capitalism, that may be enough, at least for those first few steps I mentioned above. The seemingly sedimented belief that only texts from the margins can usefully awaken people to their reified existence doesn't take into consideration the incredibly powerful hegemonizing influences of global capitalism. It is time to recognize that we can't begin at the margins and hope to bring the margins to the center. That strategy has merely kept progressive ideas where the dominant social order wants them, at the margin. No, we have to re-strategize, working from the center out, bringing people to the margin (and thus bringing the margin to the center). We begin to do that, by gaining a foothold in the mind of the reified viewer.

To further attest to this postmodern shift in the oppositional potentialities of popular cinema, I offer another angle to this debate. In contradistinction to the modernist approach of the post-'68 French film groups (journals such as Cahiers du Cinéma and Cinétheque, filmmakers such as Jean-Luc Godard, and organizations such as the Dziga Vertov group), who saw the political and the oppositional more in terms of an avant-gardist approach - as a way of getting "outside" the dominant mode of the social order - I suggest the necessity of seeing an oppositional aesthetic that is only possible from the "inside." That is, as Michael Hardt and Antonio Negri put it in their important text Empire:

We should be done once and for all with the search for an outside, a standpoint that imagines a purity for our politics. It is better both theoretically and practically to enter the terrain of Empire and confront its homogenizing and heterogenizing flows in all their complexity, grounding our analysis in the power of the global multitude (2000: 46).

As global capitalism has expanded its reach to every corner of the globe (and the unconscious, as Jameson says), as "the capitalist [world] market" becomes "the diagram of imperial power" (Hardt and Negri, 2000: 190) "the only way out," in Marco Abel's words, "is through!” (Abel, 2001: 140)

This process of "through" - of engaging a "deterritorialized" capitalism on its own terrain - I argue, begins on the most simple level (at the level of the didactically exposed mindless mass consumption in the case of American

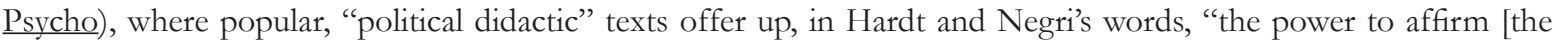
multitude's] autonomy... expressing itself through an apparatus [text] of widespread, transversal territorial [cognitive] reappropriation" (2000: 398), texts that register symptoms of the dehumanizing and destructive nature of the dominant capitalistic order. As I said, while they largely don't specifically address the causal forces that create the symptoms they relate, they do offer a glimpse of them. In addition to the didactic registers of consumerist identity formations and the dangerous consequences of this ontological shift, American Psycho also critically registers symptoms via allegorical "figurations," an important consideration for Jameson in his theorization of the postmodern moment. He says that

an essentially allegorical concept must be introduced - the 'play of figuration' - in order to convey some sense that these new and enormous global realities are inaccessible to any individual subject or consciousness...which is to say that those fundamental realities are somehow ultimately unrepresentable or, to use the Althusserian phrase, are something like an absent cause, one that can never emerge into the presence of perception. Yet this absent cause can find figures through which to express itself in distorted and symbolic ways: indeed, one of our basic tasks as critics of literature is to track down and make conceptually available the ultimate realities and experiences designated by those figures, which the reading mind inevitably tends to reify and to read as primary contents in their own right (1991: 411-412).

Because we cannot represent - and thus, confront - the enormous powerful forces (transnational, corporate apparatus/global capitalism, or in Negri and Hardt's terms, "empire") that act on us every day, we can only indirectly allude to these forces through political allegory.

Political Allegory plays a critical role in American Psycho, a film that cogently "maps" out class disparities and hierarchies - and, indeed, arguably, even this "absent cause" (again, the transnational, corporate apparatus/global capitalism) - though, most particularly, it didactically maps out a consumerism that is as monstrous in its formation of a "serial killer" sensibility as the serial killer himself.

\section{Key Differences between Novel and Film}

I want to also first say something about the adaptation of Brett Easton Ellis' notorious novel of the same 
name before I begin my analysis of the film. I'm not going to get into the on-going debate as to whether Ellis' novel was a misogynistic text (as I felt it was while reading it) or a brilliant anti-consumerism text (as I also felt it was while reading it). Instead, I want to focus on the film Harron and screenwriter Guinevere Turner adapted.[2] In one sense, Harron and Turner's adaptation is a faithful visual realization of Ellis' very visual oriented novel. In many ways the novel and film function in the same manner, as scathing satires of the hedonist 1980s in America. Harron and Turner used much of the dialogue in the book and many similar sequences. Moreover, the film retains the novel's ambiguity of whether Patrick really is a serial killer or imagines himself as a serial killer. The brilliance of this strategy is in making both "realities" possible, which allows the spectator/reader to see the (self) destructive nature of discourses of consumerism. Because such discourses have become so internalized they literally alter our "reality," blur the boundaries between "reality" and the imaginary, while collapsing the real and the imaginary into one narrative. (I'll come back to this in my discussion of Patrick's loss of self.) Whether real serial killer or fantasist serial killer, the meaning is the same since the film itself (and the novel) enacts the serial killer elements as if they are real, coding them for us as real, allegorically marking them as the Real of consumerism. Here I'm using the "Real" in the Slavoj Žižekian sense of how the Real can be shown, especially in cinema, where we can "touch the Real through those points where symbolization fails; through trauma, aversion, dislocation and all those markers of uncertainty where the Symbolic fails to deliver a consistent and coherent reality"; that is, "while the Real cannot be directly represented...it can nonetheless be shown in terms of symbolic failure and can be alluded to through figurative embodiments of horror-excess that threaten disintegration (monsters, forces of nature, disease/viruses and so on)" (Daly 2016). American Psycho superlatively does this, it reveals both how consumerist identity formations traumatically "dislocates," "disintegrates" identity, which, in turn, reveals the instability of the symbolic ("reality"/ representation) itself, a formation reliant on ideological signification in general and thus always potentially at a point of destabilization, and the film reveals the real and cognitive violence embedded in consumerism. I'll further extrapolate on this element in my "Return of the Repressed/Return of the Real" section.

The differences between book and film are significant as well. For one thing, Harron and Turner stripped the excess from the book, paring the film down to its most essential material. Most glaringly removed are the revolting details of Patrick's killings and tortures. Also eliminated are the tedious, endless details of consumer objects. My sense is that by eliminating the excessive detail of the book, especially the extreme violence, Harron and Turner turn the focus more to the political didactic dimensions of the novel. Moreover, while the novel breaks down narrative conventions in every postmodern way, the film at least gives us the facsimile of a mimetic narrative, important for the allegorical inversion the film makes, which I will come back to in a moment. As Elizabeth Young contends, the novel never gives us the anchor of a mirrored reality, nor does it give us a reliable central character:

Patrick is a cipher; a sign in language and it is in language that he disintegrates, slips out of our grasp. Patrick is Void. He is the Abyss. He is a textual impossibility, written out, elided until there is no "Patrick" other than the sign or signifier that sets in motion the process that must destroy him and thus at the end of the book must go back to its beginnings and start again (1992: 119, emphasis original).

Though the film retains this sense of indeterminacy - Patrick is still a lost signifier looking for an anchoring signified (due to his consumerist identity formation, more on this below) - the film also at least gives us the seeming moorings of a mirrored reality and gives us at least the semblance of a dimensional characterization in perhaps the most complex cinematic serial killer of all time: Patrick Bateman.

The film secures a mimetic narrative through another key change that Harron and Turner make. Unlike the novel where we only get Patrick's point of view (even when the novel shifts to an omniscient third person narration, the novel hints that it is Patrick), the film breaks away from Patrick to give us the perspectives of Others, especially women. Unlike the novel, where the women are all presented through Patrick's misogynist point of view, Harron and Turner give women in the film privileged moments. By making this shift, Harron and Turner not only offer us an anchoring reality outside of Patrick's fantasy world, they also offer us a feminine Other (that plays alongside the permeating presence of Otherness in the film) that ruptures the phallocentric narrative. The discernible presence of the feminine Other forces the spectator to see Patrick's excesses and misogyny through a woman's eye, thereby accentuating Patrick's actions as misogynistic. Again, in making this change Harron and Turner have arguably created a feminist political didactic text, as I'll show next.

\section{The Consumption of Women}

Particularly revealing is the ending moment (an added scene) where Jean, Patrick's secretary, looks at Patrick's 
appointment book and sees the horrendous, misogynist drawings of women being tortured and killed. As Jean looks down on the images of atrocities to women (us taking on her point of view), we can't help but share her shock and horror. To Jean, Patrick is the perfect "GQ" male, good looking, fit, successful, fashionable, even projecting an inexplicably all-American innocent "boy next door" quality, as he is referred to three times. So, for Jean to see these atrocities that Patrick has drawn is to see an inconceivable Patrick he so embodies an ideological "model" of perfection in Jean's eyes, a perfection that is also coded as his projected corporate image in general, an image that would typically signify an admired all "American" (Dream) sensibility. Jean's shattering comprehension is due to her only being able to see the surface of Patrick, for, like everyone else in the film, she too suffers from discourses of consumerism that are all about only seeing surfaces. But then that is part of Harron and Turner's project here, to pull back the curtain from the consumerist agenda of a supposed "perfect" surface designer status/image creation (e.g., America itself). More specifically, Patrick's "perfection" stems from him conscientiously making himself a coveted "brand." That is, via his rigorous exercise routine, tanning, and grooming himself and via his equally rigorous adherence to brand name clothes and tastes, Patrick commodifies himself, attempting to construct a much desired and valuable commodity, which of course Jean wants to consume.

That is why this moment in the film is so crucial, for Jean represents the "ordinary" plebian worker in awe of Patrick's surface "perfection" and who becomes our surrogate point of view of seeing the surface of Patrick as others see him. In finally seeing Patrick's Real "inside," the spell of "perfection" is shattered, which, in terms of Patrick's allegorical signification, has profound implications. For one, what American Psycho does so well is didactically deconstruct this projection, again and again revealing the violence embedded in the consumerist brand name. In this case, the brand of "Patrick" hides a monstrous objectification, dehumanization of and violence against women.

This glaring embedded violence in consumerism is repressed in society, a necessary thing in order for such a destructive system to remain in place. The more profound point here is the ambitious trajectory this film takes with Patrick, a conspicuously allegorical figure if there ever was one (e.g., for one thing, he is an "American" psycho), a crucial element in the film that I will reveal in the course of my analysis. For now, in this moment, these misogynist drawings by Patrick take on much deeper implications than simply Jean seeing Patrick's misogyny and psychopathy. Allegorically, Patrick is signified as quintessentially American: phallocentric, patriarchal, capitalistic, consumerist. At least in terms of "patriarchy" (but expanding this sentiment to these other aspects of the ideological) Jane Caputi puts this moment simply: "Generally, awareness that this society is a patriarchal one, that is, committed to committing atrocities against women, is repressed" (1993: 104). In this scene, that ideological "repression" didactically erupts into the clear view of sight and consciousness for Jean and us.

Another moment bares this allegorical misogyny out, a moment that very much prefigures the appointment book moment. This moment is in the book as well, but as I have tried to argue, because of the feminine presence in the film (versus their lack of a tangible presence in the novel) this moment becomes more interrogative. Patrick's friends are degrading women in the usual objectifying locker room banter. Patrick's contribution to this discussion is particularly repellent. He tells them what serial killer Ed Gein had to say about women: "He wondered what [a woman's] head would look like on a stick." By inserting this extreme comment into their seemingly typical casual male conversation, Harron and Turner (and Ellis) are again (along with the later drawings revelation) revealing the Real (or return of the repressed) latent within his colleagues' pernicious comments. By making this revelation, Harron and Turner show how the misogyny and objectification of women is part and parcel of a destructive part of consumerism that markets women's bodies like pieces of meat, even more telling in a film where this cliché takes on literal meaning.

Like Jean, "Christie," the prostitute who Patrick picks up, is also given a point of view. Unlike the other characters (except Jean and the homeless bum $\mathrm{Al}$ and perhaps tragic Courtney) that feel no emotion and have no conscience that we can discern, "Christie" exhibits human characteristics, an important move on Harron and Turner's part. By giving "Christie" her humanity, her commodification and consumption becomes all that more apparent and painful for us. The second time Patrick picks her up, her desperate straits overcome her agitation from Patrick's previous severe abuse, "Christie" is obviously distressed at being in Patrick's company again. At this point, we have a real investment in her well-being due to what she has endured thus far, and the fact that she is so desperate for money that she will endure more. Tanner aptly expresses the painfulness of "Christie's" situation:

The power of the john, who is able to repair and repurchase even a damaged body by producing money, anticipates the explicitly violent force of the psychotic killer who is able to transform the individual subjective body into typical, 
physiological matter by producing a weapon. As a critique of the dangers of ' 80 s capitalism, American Psycho suggests that not only the john but any powerful capitalist manipulates and violates bodies in the process of buying and selling. The psycho, then, merely extends logically the assumptions of capitalism as he translates human bodies into commodities subject to both physical and economic manipulation (1994: 97).

Again, this figuration of Patrick into something more than merely a typical serial killer and "Christie" as something more than a disposable victim, didactically "unveil[s] the machinery that creates the magical illusions of a psycho-capitalist world in which the wealthy and beautiful have the power to transform anything into anything" (Tanner, 1994: 98). In this case, Patrick (re)names "Christie" (and "Sabrina") and transmits internalized narratives of consumerism (pornography and "torture porn" serial killer/horror film narratives, especially the chainsaw wielding Leatherface in The Texas Chainsaw Massacre) that literally use women's bodies for his/its consumption needs. These are the extreme ends of an overall sexist and misogynistic pattern throughout where Patrick is always telling women how to dress and look and behave and what to say. In other words, in allegorical terms, Patrick embodies a consumerism/capitalism where women are purely commodified players in his/its consumerist identity-consumption enactments.

Caputi takes this point even further, suggesting a deeper level of animus towards women: "Although this is rarely openly admitted, patriarchal culture does indeed require the ritual sacrifice of women, sometimes called witches, sometimes, prostitutes, sometimes even feminists" (1993: 106). Resonating here of course is the "serial killer" sub-genre itself, a disturbingly popular sub-genre of the horror film presently in currency, a fact that I believe Harron and Turner were aware of, making the film a kind of metanarrative as well, encapsulating the very real dehumanization of this pernicious sub-genre.[3]Indeed, Caputi sees the "ascendency" of the serial killer as the height of this dehumanization of women:

[T] he ascendancy of the serial killer is a harbinger of apocalypse for the culture that has immortalized him, a culture that enacts on a grand scale an attack on the feminine, women and often literally the womb (as in the crimes of Jack the Ripper), understood within our tradition to be an assault on the core source of life and, hence, the future itself (1993: 107).

Again, my sense is that Harron and Turner are meeting Caputi's implicit challenge, by elevating Ellis' original narrative to a grander allegorical level, placing the blame for misogyny not only on patriarchy ideology but on consumerism/capitalism as well. No scene in any film that I can think of makes this clearer than this one: Patrick is apparently performing cunnilingus on his "friend" Elizabeth (played by Turner no less). To our (and "Christie" whose point of view we share) horror, he begins to literally eat her. By making her vagina the body part of choice for his appetites - not coincidently, the symbolic locus for life's entry way - Turner and Harron hyper-accentuate the misogynistic nature of the "serial killer" sub-genre. However, that only begins to get at the relevance of this moment and how it climaxes the commodification of women in general, as I will reveal in a moment.

Many writers have made the cannibalism/capitalist-consumerist analogy. For example, Michelle Warner contends that American Psycho "depicts the end project of a society that teaches its members only to consume others. American Psycho takes psychological cannibalism to its physical extreme, that of true physical cannibalism" (1996: 144). Caputi explains this interesting phenomenon:

To understand why cannibalism has become a major motif in horror film and fiction since the 1960s, we might consider it as a metaphor for, in a word, consumerism. A corporate consumerist society is inherently ravenous, devouring natural resources and ever insatiable for new mass-produced goods. Perhaps [Hannibal] Lecter (and the actual sex murderer and cannibal, Jeffrey Dahmer) so grip the collective imagination in part because they mirror gluttonous American incorporation of the land and resources (bodies) of others, most frequently racial others (1993: 105).

Laura E. Tanner reinforces Caputi's and Warner's sentiments by showing how the capitalist devalues (dehumanizes/“consumes"/eats) the (disposable) human body:

In using money to make money, Marx's capitalist profits without labor; he trades in the abstract and the invisible at the expense of those whose bodies are visibly used up by his exploitation of them. Marx's descriptions of the capitalist's dealings stress their apparent magical quality, the ease with which the capitalist is able to make something out of nothing. In doing so, of course, the capitalist also turns something into nothing; he transforms human beings into material: 'Production does not simply produce man as a commodity, the human commodity, man in the role of commodity; it produces him in keeping with this role as a mentally and physically dehumanized being' (Economic and Philosophic Manuscripts, 1844: 121). The 'increasing value' of the capitalist's world not only results in but depends upon what Marx describes as 'the devaluation of the world of men' (1844: 107). Whereas Marx's work on economy traces capitalism back to its origin in the gritty sacrifice 
of the worker's mind and body, American Psycho pushes the capitalist mentality to an extreme that renders visible the machinery at work beneath its apparent magic (1994: 96, original enphasis).

Indeed, as Tanner so skillfully conveys, that is what American Psycho didactically realizes, the absolute commodification (literal de-humanization) of self and Other. To further accentuate this uber-commodification, we can see how this consumption/cannibalism analogy is the Real of a capitalistic system.

To look at this film from this angle and to further demonstrate the differences between novel and film, I want to look at one particularly important moment, Harron's clever opening sequence.

The film begins with what looks like a knife cutting something (presumably human) and blood spewing forth. However, the blood is not blood but a red sauce and the knife is cutting, but it is cutting food. The opening image, then, is a clever ruse: What we think we see isn't what we see at all. That speaks to four different points: First, it manifests in a nutshell the operating mechanism of the film, the blurring of boundaries between reality and image, or discourses of consumerism, between what we think we see and what may in fact be Patrick's imaginings, which, in turn, reveals another pernicious consequence of consumerism, the breakdown of the "reality" "chain of signifiers" where signifiers of consumerism literally become our "reality" (more on this below). Second, it speaks to the most bizarre and telling aspect of our discourses of consumerism, our image conscious society, where even food is packaged, fetishized, in an imagistic (designer) way. Third, it begins the film on the most pernicious image of consumption, eating exotic, extravagant (wasteful) foods while Others in the world eat little or nothing, the larger point of which is that consumerism itself is about putting consumption and branding (or hedonistic pleasures) before all else. In this sense, then, this opening moment already speaks to the Jean moment I discussed above, the facade that consumerism perpetuates (the glossy, designer world), and the underlying, murderous Real (blood/violence).

To further highlight these ideas, the film's opening becomes a recurring motif in the film: Many of the sequences in the film involve food consumption (or attempting to get "reservations" for food consumption). The characters in the film are often seen eating out and Harron often emphasizes the fetishized nature of designer food dishes. In one telling moment in particular, just after Patrick has improbably killed "Christie," we get a cut to another designer food dish. After lingering on this image for a moment, Harron then tilts down to reveal that Patrick is drawing an image of his recent kill (or, more probably, the image speaks to an imagined kill[4]).Adding to this provocative image is yet another motif in the film, the color pattern of red, white, and blue. Not only is the facsimile image of dead "Christie" drawn in red and blue (set against the white table cloth) but the dish is prepared on a blue dish with a white dusting of powdered sugar, red berries on top, giving the dish itself the dominate coding of red, white and blue. Throughout the film, we see this red, white and blue color coding, especially in some of Patrick's suits. In this way, Harron emphasizes what I've suggested above, that not only has food been commodified but that - in linking the designer food to murdered, commodified "Christie" - food consumption is being equated to the consumption of women - consumption conspicuously associated with American ideology - a consumption too that has, via the serial killer sub-genre and other "torture porn" sub-genres of the horror film, been also commodified. In other words, this film constructs an extremely complex and disturbing picture of consumerism where (A) virtually every facet of life has become commodified, as will become more clear in a moment, and (B) most egregiously targets women as the most commodified and consumed Other.

In this shifting of point of view and focus (e.g., to a feminine presence in the film), again, Harron and Turner have made Ellis's vision their own, didactically emphasizing the commodification of women. Compounding this allegorical political-didactic meaning is a personal political-didactic one as well: Consumerism dehumanizes Patrick robs him of his empathy - which, in turn, conjoined with discourses of consumerism that commodify women, turns him into a consumer of women, a thread I will explore more in the next section.

\section{| Patrick's Consumerist Identity Formation}

Along with the dehumanization (consumption) of women, the film's other principal focus is on the dehumanization (consumption) of the self. Again, perhaps more devastating than any other film that focuses on consumerism American Psycho reveals the utter loss of self from consumerism. What is so hideous about this aspect of consumerism is how recent research suggests that consumerism plays a part in the degradation of empathy, which, in turn, is a major factor in the materialization of psychopaths and the concurrent consumption of women. 
Again, we distinctly see this outcome with Patrick, who enacts discourses of consumerism that explicitly encourage the consumption of women, e.g., principally serial killer narratives, fiction or non-fiction (especially punctuated by his fixation on The Texas Chainsaw Massacre) and pornography though we also get body image messaging (the men's locker room banter) and phallocentric narratives (e.g., the cowboy signifier in Patrick's room and many phallic moments, especially the business card duel). This dehumanization of the self stems from an identity formation that is largely produced by consumerism. In their essay "Globalization, Corporate Culture, and Freedom," Allen D. Kanner and Renée G. Soule say, "[W] hen people are advertised to, they are objectified in a very specific manner. Their value and worth as a human being is reduced to that of a consumer. As a result, people's identity becomes increasingly based on their ability to buy things. They also judge others by the same criterion" (2003: 57). Tim Kasser affirms this experiential reality:

\begin{abstract}
In the face of messages glorifying the path of consumption and wealth, all of us to some extent take on or internalize materialistic values. That is, we incorporate the messages of consumer society into our own value and belief systems. These values then begin to organize our lives by influencing the goals we pursue, the attitudes we have toward particular people and objects, and the behaviors in which we engage (2002: 26).
\end{abstract}

This internalization of "materialistic values" then leads to a devaluation of Others:

When people place a strong emphasis on consuming and buying, earning and spending, thinking of the monetary worth of things, and thinking of things a great deal of time, they may also become more likely to treat people like things. Philosopher Martin Buber referred to this interpersonal stance as I-It relationships, in which others' qualities, subjective experience, feelings, and desires are ignored, seen as unimportant, or viewed only in terms of their usefulness to oneself. In such relationships, other people become reduced to objects, little different from products that may be purchased, used, and discarded as necessary (Kasser, 2002: 67).

Disturbingly, Kasser goes on to say that "it is not hard to find examples of I-It relationships and objectification in consumer-driven cultures, as they have become increasingly common" (2002: 67). In terms of Patrick in particular, his actions and choices suggest a narcissistic personality, a disorder potentially "bred" from consumerism: "Narcissists are typically vain, expect special treatment and admiration from others and can be manipulative and hostile toward others. Social critics and psychologists have often suggested that consumer culture breeds a narcissistic personality by focusing individuals on the glorification of consumption" (2002: 12) In his essay "Seriality Kills," Frank Dexter affirms this reality of consumption, where "commodification... is the official substitute for social interaction...[now] the normal form in which wants are to be satisfied, freed of the oppressive complications of reciprocity, obligation, uncalculated generosity and all the other antiquated vestiges of a bygone symbolic order" (1992: 29).

We see Patrick's dehumanized, consumerist state most clearly early on, in one of the most striking scenes in the film, when Patrick takes us through his beautifying routine, capped off by applying a beauty mask to his face. As he is peeling his mask off, we hear in voice over:

There is an idea of a Patrick Bateman, some kind of abstraction, but there is no real me, only an entity, something illusory, and though I can hide my cold gaze, and you can shake my hand and feel flesh gripping yours, and maybe you can even sense our lifestyles are probably comparable, I am simply not there.

Removing a mask usually means revealing the true persona underneath. For this moment, however, the removal of Patrick's mask reveals not a true (authentic) self underneath, but rather, a consumerist ("not there") self. And, indeed, Patrick doesn't seem to be there for much of the film. His fellow workers often do not recognize him and his reflection in various objects (on a framed print of the play Les Misérables [5], in the cab with his fiancée, on a menu) are constantly blurred. By not being linked to humanity, consumerist-Patrick is set adrift in a sea of signifiers. Patrick becomes a sliding signifier (and others in his circle as well) to which multiple signifieds can be attached. It is not only that Patrick is mistaken for his fellow "vice presidents" (a recurring joke that occurs amongst the other characters as well, everybody mistaking everybody for someone else), but he also seems interchangeable with them, making them all in a sense a designer construction. Warner recognizes the extreme danger in this development: "The native society is now dangerous because it devalues personal perception and any formation of internal identity. In this society people are identified in terms of what they wear, what they buy, and how they look" (1996: 141).

Patrick's consumerist existence stems from a systemic "consumption of identity" (Warner, 1996: 141) and the power of American Psycho is in its giving us a textbook, didactic representation of what this consumerist world looks like, so valuable for mainstream audiences who to one degree or another have suffered from the same consumerist 
identity formation and have few texts to inform them of their de-realized self-formation. In one striking example, Bryce disingenuously talks about how they should all concern themselves with "the massacres in Sri Lanka..., how, like, the Sikhs are killing, like, tons of Israelis over there.” But he merely conveys this to project an image of erudition and philanthropy. Patrick responds likewise (in an unaffected tone, registering the falsity of his monologue) with a litany of other causes:

There are a lot more important problems than Sri Lanka. We have to end apartheid for one, and slow down the nuclear arms race, stop terrorism, and world hunger. We have to provide food and shelter for the homeless and oppose racial discrimination and promote civil rights while also promoting equal rights for women. We have to encourage a return to traditional moral values. Most importantly, we have to promote general social concern and less materialism in young people.

Unlike everyone else at that table (and the film), Patrick conveys this list with full self-awareness that he (and his "friends") doesn't really care. In a consumerist state of being, one can only go through the motions of caring about real world concerns. Similarly, it is also clear that global capitalism discourses (and its embodied figurations) only account for the lesser fortunate as a necessity of maintaining its consumerist human(e) facade. As Juchartz says, "Bateman has just been mouthing the same 'outrage' voiced by contemporary political leaders and civic groups.... The outrage consists of no more than words; there are no actions associated with them, other than a continuation and even escalation of the violence and amorality being protested" (1996: 73).

Juchartz only gets this sensibility partially right: It isn't that Patrick is doing the same thing as “political leaders and civic groups" but rather that he has consumed canned consumerist political rhetoric into his identity formation. That is, Patrick's identity is purely an amalgamation of consumerist signifiers. Virtually everything he says and does and wears and eats is internalized signifiers of consumerism regurgitated. In addition to the above consumerist rhetoric, we see this most conspicuously during one sexual encounter with "Sabrina" and "Christie" where, again, the sex is emulated from pornography (and, indeed, he films the scenes and narcissistically "performs" for the camera). We also get Patrick using consumerist slogans ("Just say no"), incessantly dropping brand name references (and clothing himself and surrounding himself with brand name objects), repeating a food critic's review of a "tasty dish," name dropping famous character names ("Cliff Huxtable") and, most hilariously, waxing (canned) philosophies that seem to emanate in part from the shallow meanings of pop songs themselves and in part from reviews of the music, all of which are substitutes for authentic identity markers. Most disturbingly, he imitates chainsaw wielding Leatherface, yet another figuration for how discourses of consumerism are not innocuous (e.g., food or clothes consumption) but rather inevitably extends to more explicit forms of (self) destructive modes of patterning.

\section{| "I've got to return some videotapes"}

Patrick's lack of self-manifests itself in a subtle way as well. Throughout the film, Patrick sprinkles numerous popular catchphrases and lines ("I want to fit in"; "you look marvelous"; "it was a laugh riot"; "I'm on a diet" to list just a few) into his comments and responses to other characters. Patrick uses these catchphrases as ready-made responses to character conveyances, which further accentuates what I convey above, that Patrick has no authentic center of being but rather not only internalizes language, interests, belief systems and so on from discourses of consumerism and name brand objects but fills his self with popular colloquial language he consumes from others. That is, because Patrick so utterly lacks an authentic self - because consumerism signifies him - with real (historical, cultural, familial, societal) values and beliefs (an "inside") he is as Young says above, literally a "cipher...void." The implications of this are profound: Not only is Patrick's core identity determined by consumerism, but the people around him become an extension of consumerism and objects for his consumption in every way possible, from appropriating their language to appropriating their identities (at least twice he becomes others - Marcus Halberstram and Paul Allen), as well as literally consuming bodies for his every need - especially, again, women - or, at least so it seems, a (cannibalistic) metaphor that informs every other appropriation.

This reification process is so transparent because Patrick uses these catchphrases even when they are obviously inappropriate, as if because he has no "inside" to call up his own calculated responses, he can only respond with commonly used lines, even if they are inappropriate. No line best exemplifies this meaning than the line "I've got to return some videotapes."

The first time Patrick uses the line is as an escape mechanism to flee Luis's surprise come-on to Patrick (though, 
intriguingly, the fleeing seems to be more about a homosexual panic on Patrick's part, Patrick apparently suffering from repressed homosexuality). He later uses the line in response to "Detective Donald Kimball" asking him where he was on the night of Paul Allen's disappearance ("I guess I was probably returning videotapes") and when a distressed Evelyn (Patrick has just broken up with her) asks a retreating Patrick where he is going ("I have to return some videotapes"). In all three cases, the line is extremely incongruous to the characters' questions, which, to my mind, is in part why the line is amusing: The line-as-response perplexes us because it is such an inexplicably unsuitable response. Moreover, the line is also wildly incongruous because Patrick does not have to return videotapes! That is, at various times, he probably does have to return all of those videotapes we see playing in the background (e.g., pornography and The Texas Chainsaw Massacre); however, since he has excessive wealth, late fees and even the expense of an unreturned videotape can't register as an immediate or necessary need. In this sense, the line becomes even more transparently ridiculous (and thus humorous). More pertinently, again, this transparent incongruity reveals Patrick as being a transmitter of internalized consumerist signifiers.

Disturbingly, Patrick's arbitrary responses reveal how consumerism in general "breaks down the signifying chain," a deeply profound shift in postmodern being and meaning creation as Jameson elucidates:

\begin{abstract}
When that relationship breaks down, when the links of the signifying chain snap, then we have schizophrenia in the form of a rubble of distinct and unrelated signifiers. The connection between this kind of linguistic malfunction and the psyche of the schizophrenic may then be grasped by way of a twofold proposition: first, that personal identity is itself the effect of certain temporal unification of past and future with one's present; and, second, that such active temporal unification is itself a function of language, or better still of the sentence, as it moves along its hermeneutic circle through time. If we are unable to unify the past, present, and future of the sentence, then we are similarly unable to unify the past, present, and future of our own biographical experience or psychic life. With the breakdown of the signifying chain, therefore, the schizophrenic is reduced to an experience of pure material signifiers, or, in other words, a series of pure and unrelated presents in time (1999: 26-27).
\end{abstract}

Among the many consequences of this break down is what Jameson calls "the waning of affect," a "liberation... from the older anomie of the centered subject" which means a "liberation from every...kind of feeling [and emotion]... since there is no longer a self present to do the feeling" (1999: 15) and a "psychic fragmentation" where "the structural distraction of the decentered subject [is] now promoted to the very motor and existential logic of late capitalism itself" (1999: 117). In other words, this consumerist (postmodern) subject is a temporal cipher detached from any grounding whatsoever - historical, cultural, societal, familial, (inter- and intra-) personal - ontologically designed instead by discourses of consumerism schizophrenically (euphorically) existing purely for consumption and...commodification. Perhaps no other fictional character embodies this mode of being better than Patrick, a human turned into a free floating signifier of consumerism detached from these very (historical, cultural, societal, familial, personal) links that make us human - give us a sense of our place in the world and history, symbiotically connect us to the material matter of our environments, empathetically relate to others and cognitively comprehend how our actions and choices impact the "global village" we inhabit.

Interestingly, as a by-product of this signification, this line also reflects a mundane, normative state of being outside of Patrick's otherwise affluent ostentatious decadent lifestyle (normal people do indeed have to worry about "returning videotapes"), which, in turn, further emphasizes the incongruity of this line because it emphasizes the real class disparity between corporate Patrick (who uses the line as an empty signifier) and the rest of us whose first response is in relating the real need to..."return those videotapes."

\title{
Patrick's (Our) Prison of Consumerism
}

Paradoxically - unrealistically - the element in the film that perhaps gives it its most unique flavor while also heightening this loss of authentic self is Harron and Turner choosing to give Patrick himself his humanity - in personalizing the severe consequences of consumerism on his humanity and in his awareness of his lack of it.

American Psycho has no hero to speak of, no figure that we can suture our point of view into, no real moral center, unusual for the serial killer sub-genre. With no moral center and no hero figure, no collapse into the too easily rendered dichotomy of good and evil, and with a characterization of a serial killer that offers some realization of his (lost) humanity, the film gives us nowhere to go but Patrick.In some ways, this "no moral center" strategy gives us a Brechtian distanciation effect (e.g., because we aren't sutured into anyone, we are kept at a distance). However, 
I would also argue that because the film gives Patrick an anguished state of being from which we can relate - a consumerism that we all feel is dehumanizing us to some degree - we can't help but come to some investment in Patrick. In this way, then, the film takes on an even more complex web of identity formation: Instead of devolving into the typical Christian mode of "evil" for causal monster identity formations (e.g., even when not spelled out, the lack of cause is assumed to be just that, some simplistic ill-informed notion of soul-less "evil") or suggesting some specific "reason" for a monster's evil-ness (e.g., abusive parenting), the film targets instead the system itself - e.g., consumerism/capitalism - truly rare in commercial cinema. That is, I would argue that the point both film and novel make (though the film it seems to me gets this across better) is that Patrick's psychotic, murderous state is inevitable in a system that so dehumanizes its inhabitants. To attribute his state to some specific causal mechanism would be to do what most texts do, make his illness a symptom of something specific and correctable in society instead of "seeing" the deeper truth, that specific causes are merely symptoms of a deeper, much less easily graspable and correctable problem: capitalism itself.

In a mesmerizing performance, Christian Bale perfectly captures the torment of Patrick, his visage and comments always revealing his self-awareness (in a sea of figures who have no clue) of the "horror" of this consumerist world and his own part in it and in the constant suffering that such a prison of consumerism brings him, especially in terms of his experiences in attempting to measure his worth as a commodity (via adopting a consumerist self) against other "self" commodities. In this sense, though we are sickened by Patrick's acts we cannot fully dismiss him as a monster

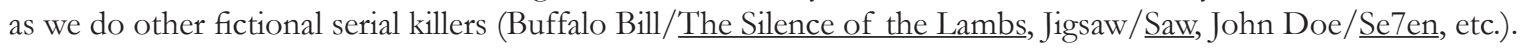

In terms of Patrick's self-awareness, we see this self-knowledge in many ways, via his actual words and thoughts, e.g., him knowing that he is "not there" (see above) and that there is "no inside" (see below) but also in other ways as well, such as him writing "Die Yuppie Scum" in blood on a wall, a line that suggests Patrick's deep rooted hatred for his "yuppie" lifestyle. Patrick's tormented state goes much deeper than this however; indeed, Harron and Turner gives us a serial killer who is as much victim and victimizer, perhaps more so if Patrick has not actually killed anyone. Harron and Turner do this in two principal ways: Psychologically speaking, by making him an extremely vulnerable serial killer and by emphasizing his critical lack of a real, meaningful human connection in his life.

In terms of the former, we get this most strikingly in the business cards duel sequence, for me, the single most interesting "phallic" symbol sequence in film history (for one thing, it links reinforcing masculinity to consumerism/ capitalism in complex ways, a subject for another paper). In this sequence, Patrick "draws" his new business card, thinking his new card to be superior to his colleagues, but as others reveal their own new cards, it becomes clear that Patrick's card is the weakest of the bunch (even though for us they all look alike). Since Patrick's sense of worth is symbiotically attached to consumerist status symbols (as is typically the case with consumerist identities) him losing the business cards duel (especially as his card is apparently vastly inferior to his nemesis's card, "perfect" Paul Allen) is beyond devastating to him, for these crushing losses of status symbols are constant castrating stabs to Patrick's self-worth. Harron emphasizes this shattering loss of "self" with her extreme close-up of Patrick's sweaty, distorted, pasty facial features, an extreme and telling break from the "perfect" façade that Patrick projects up until this point. Though this moment is the stand out moment for Patrick's loss (lack) of self-worth, Harron and Turner gives us many moments like this where again and again, Patrick's symbiotic attachment to consumerist status symbols fail him - as they invariably will - and reveal an inexplicably vulnerable serial killer - because he is a deeply insecure individual whose sense of self-worth rises and falls according to the success or failure of commodity status symbols (e.g., the status acknowledgement of Others). As Kasser says, consumerism creates individuals whose "sense of esteem is frequently threatened, and their feelings of competence and worthiness are tenuous, even when they succeed" (2002: 48).

In terms of the latter - Patrick's lack of a meaningful connection (replaced by a drive for consumption of objects) - Harron and Turner emphasize this lack of Patrick's by giving us the barest hints of Patrick's suppressed desire for a genuine relationship with his secretary Jean, which we especially see in one of the most complex sequences in the film. Patrick and Jean are about to go on a date. To our horror, Patrick seems ready to kill her with a nail gun. However Patrick's seeming choice to kill Jean is thwarted by fiancée Evelyn's phone call. After Evelyn leaves a message on Patrick's machine, Jean asks Patrick if he wants her to leave. With a pained look on his face, Patrick responds, "Yeah, I don't think I can control myself... I think if you stay, something bad will happen. I think I might hurt you." This moment of mercy and empathy for Jean reveals some "shred of humanity" left in Patrick. However, since research has shown again and again that serial killers have no empathy and thus see their victims as nothing more than disposable objects - which is otherwise very much the case elsewhere in the film - that simply cannot be the case here. And yet inexplicably it is. That is why I say "unrealistically" above. Harron and Turner choose to give Patrick that "shred of humanity" I just said was impossible for him to have. They do that to have their cake and 
eat it too so to speak. That is, they get their ostensible serial killer horror film but they also get something more, a horror film with political content. In short, again, by giving Patrick his humanity in moments such as this scene - in his inability to form meaningful attachments - Harron and Turner reveal in his utter commodification a human as a victim, a necessary move to activate our own sense of loss in the face of a dehumanizing consumerism that has imprisoned all of us.

Later, in another key Jean moment, really falling apart now, Patrick calls Jean and says, "I need help.... I don't think I'm going to make it Jean." Here again we see Patrick's real latent desire for a real connection, a real relationship with one of the few "real" individuals in the film - Jean - break through his self-absorbed consumerist self. In this latter scene, despair setting in as his carefully constructed alternative reality - again, crafted together from discourses of consumerism (though, interestingly, this break down also activates discourses of consumerism as well as we see with the over-the-top confrontation with police) - breaks down, Patrick is in full blown panic mode. His call to Jean suggests him reaching out to the one human being he knows genuinely cares about his well-being, making Patrick despite him also being horribly repellant - at least in moments such as these, a pathetic and even sympathetic figure.

In humanizing Patrick, Harron and Turner situate Patrick with the most complex cinematic serial killers in film, Norman Bates ( $\underline{\text { Psycho }}$ ) and Mark Lewis (Peeping Tom $)$, both of whom are also arguably sympathetic and vulnerable serial killers, though unlike those two figures - whose psychopathy stems from parental origins and perhaps make them less relatable - Patrick's psychopathy at least in large part, or inextricably linked to any other implicit origins, stems from something we can all relate to, dehumanizing consumerism, a distinction that makes Patrick unique indeed.

Patrick's displaced humanity perfectly supports research on the devastating consequences of a consumerist lifestyle. As Kanner and Soule say, "Corporate policy and actions [e.g., advertising, marketing, consumerism] often compromise both outer and inner freedom, with dire psychological consequences” (2002: 50). Mihaly Csikszentmihalyi asserts "that excessive concern with financial success and material values is associated with lower levels of life satisfaction and self-esteem, presumably because such concerns reflect a sense of 'contingent worth' predicated on having rather being” (2003: 102, His italics). Erika L. Rosenberg cites Eric Fromm's work to support this consumerist process of "self" degradation:

In psychology, Fromm (1947) proposed a personality type that can emerge from an isolated self in a consumer economy: the marketing character. People of this type have so lost a sense of inherent worth and connection to others that they have come to see themselves as a commodity. Seeing oneself as a commodity comes from a sense of isolation, which ultimately stems from the fundamental human need of interrelatedness that is not being met (2003: 113).

Finally, Kasser emphasizes how consumerism can lead to life and self-diminishment:

$[S]$ tudies document that strong materialistic values are associated with a pervasive undermining of people's well-being, from low life satisfaction and happiness, to depression and anxiety, to physical problems such as headaches, and to personality disorders, narcissism, and antisocial behavior (2002: 22)

What these scholars have discovered in their research on consumerism is just how dehumanizing consumerism is - in so many ways and so many levels - and yet we continue to inexplicably embrace our own self degradation, a sign of our own psychosis, an inversion the film didactically makes, as Scott Wilson suggests:

On the sound Catch-22 principle that the very act of declaring one's madness is proof of one's sanity, while active, unreflecting participation in society (i.e. flying more missions) is evident lunacy, so it is not Bateman who is psychotic but America itself. Bateman knows that he is an amoral killer in an amoral universe, he is not deluded....While he is amoral, Bateman still discloses, at various points, an ill-defined anguish... (2000: 496).

Wilson's inversion here - that it is America that is "psychotic" - because of this "unreflecting participation" in a system that systematically dehumanizes human beings - whether that be from "flying more missions" or consumerism - signifies a consciousness "lack," stemming from a "consumerist consciousness." Harron and Turner especially signify this inversion in another potent inversion scene.

The film and novel both end with Patrick being juxtaposed with a clip of former President Ronald Reagan playing on a TV set. In both book and film, we roughly get the same provocative commentary by Patrick's associate Timothy Bryce. In the film, Bryce says, "How can he lie like that? How can he pull that shit? How can he be so fucking, I don't know, cool about it? He presents himself as this harmless old codger, but...inside...but inside....” Patrick finishes Bryce' commentary with his interior "but inside doesn't matter." Explicit in these comments is the 
fact that Reagan, like Patrick, is all surface and no depth. That is, Reagan and Patrick are both media/consumerism creations. In the film, however, this juxtaposition becomes more explicitly a doppelganger effect as Patrick is set in a kind of mirror shot exactly opposite Reagan's image on TV. Further emphasized by his red, white, and blue suit, Patrick then becomes a didactic figuration for Reagan himself: Patrick becomes a stand-in for the dominant American order. Conversely, Reagan becomes the "American psycho."

And that then becomes the film's radical "revolutionary" commentary: The "American" in the title American Psycho is not about one individual - Patrick Bateman - but rather it directs us at another kind of American "exceptionalism" (change the title to this: American: Psycho) an American sociopathy that stems from the consumerist identity formation that I have been discussing in this essay. Compounding all of this though is yet another dehumanizing element: As Patrick expresses at the end, when everyone is a product of a consumerist identity formation, there is no way to "confess" (or see) one's murderous desires - and thus "no exit" (as the door just behind Patrick in that last scene conspicuously signifies) from the inevitable slide into a consumption of Others - since everyone has lost their "inside." That is, in the proverbial "vicious circle," as we become more commodified and reified and thus can't see our dehumanized state, we take ourselves even deeper into a commodified (reified) state of being, which, in turn, blinds us even more to the commodification process and so on.

This loss of self to a consumerist identity formation has an even more profound disturbing implication: Perhaps no power on earth blocks real political awareness, political investment, and political collectivity more insidiously than a consumerist identity formation that is wired for self-absorption and for desocialization. And that then is why this is a didactic message that cannot be undervalued, a message of just how truly devastating - devastating for self but also devastating for society - consumerist modes of identity formation are. That this message is consigned to a "popular" film makes the potential imprint of this message all the more impactful. Framing these important messages in a popular text may be the only way enlightenment takes place for reified audiences who only survey mainstream texts and whose cinematic language, so to speak, is the "language" of mainstream cinema. That, too, then informs why American Psycho is not only a vital political didactic text but a "revolutionary" one as well, a description that fits well for Robin Wood's famous proposition of the potential power of the horror genre.

\section{The Return of the Repressed/The Return of the Real}

Wood's suggestion in his seminal essay "An Introduction to the American Horror Film" that the horror genre is a potentially revolutionary genre, because it so artfully disguises its revolutionary material and because it reveals the "return of the repressed" of society - and the concurrent underlying ideological power mechanisms that oppress self and Others - is exemplified in American Psycho. Coincidentally, spelling this concept out is Wood's analysis of the grotesque family in The Texas Chainsaw Massacre, the distorted shadow ("return of the repressed") of our American capitalist system. That is, the family is a literal indictment of a capitalism that leaves human debris in its wake (they are the remnants of a slaughterhouse that was shut down), and a figurative marker of our distorted, repressed shadows staring back at us, human beings turned into cannibals (capitalists). Wood reveals the "distinction the film makes between the affluent young [protagonists] and the psychotic family, representatives of an exploited and degraded proletariat" (1985: 212). In a similar way, American Psycho offers us another kind of figurative ("return of the repressed") marker: Though still a monstrous capitalism that eats its own, in accordance with the shift to global capitalism, the nightmare has now become the omniscient presence of the transnational, corporate apparatus and its omniscient symbiotic arm, consumerism, all allegorically signified by corporate-consumer-cannibal Patrick Bateman. This sensibility is best exemplified by Patrick's "return of the repressed" turn of corporate phrases (e.g., "mergers and acquisitions" becomes "murders and executions") and by the name of Patrick's corporate master "Pierce and Pierce" which also didactically reveals the violence implicit in its predatory business of "mergers and acquisitions."

In a complementary vein, American Psycho also registers the deeper traumatic register of the "return of the Real":

Just as the inevitable return of the repressed undermines the fantasy of unity that is the ego, so also does the return of the Real highlight the inadequacy of capitalist ideology, which revolves around the imaginary object that is the ego. Moreover, the return of the Real as traumatic intrusion (e.g., economic and ecological crises), reveals the masturbatory idiocy implicit to global capitalism's injunction to ever more enjoyment (Kelsey Wood, 2012: 310). 
If we replace "consumerism" with "global capitalism" (though consumerism is part and parcel of global capitalism) we can especially see how telling this "masturbatory idiocy [for]... ever more enjoyment" is, a more glaring (symbolic) "fantasy frame." In these Žižekean terms, the Real in this film is a symptom of "an unbearable truth" that "resists integration" into the social order. This is the great Žižekian inversion, where the Real functions as the "real truth" of the symbolic order:

[I]t should...be clear how 'identification with the symptom' is correlated with 'going through the fantasy': by means of such an identification with the (social) symptom, we traverse and subvert the fantasy frame that determines the field of social meaning, the ideological self-understanding of a given society, i.e., the frame within which, precisely, the 'symptom' appears as some alien, disturbing intrusion, and not as the point of eruption of the otherwise hidden truth of the existing social order (Žižek, 1995: 140).

The genius of the film is that it takes our consumerist reality, or "fantasy frame," and through representation - through Patrick and Patrick's psychotic consumerist-fantasy "reality" - reveals the "hidden truth" (or the Real) of the symbolic order itself, this capitalistic transversion of our "reality" into a "consumerist" (hedonistic, narcissistic, simulacrum) "reality." But, then, in a manifold effect, the film registers the Real of this consumerist symbolic order itself, a compounding of the deeply disturbing ramifications of consumerism. In another revealing passage, where Žižek discusses Fritz Lang’s classic film Woman in the Window, Žižek gives us another example of this inversion. In the film a professor dreams he kills a man. Žižek inverts the discourse:

The message of the film is not consoling, not: 'it was only a dream, in reality I am a normal man like others and not a murderer!' but rather; in our unconscious, in the real of our desire, we are all murderers.....we could say that the professor awakes in order to continue his dream (about being a normal person like his fellow men), that is, to escape the real (the 'psychic reality') of his desire (1995: 16, His italics).

In the same way, then, we can say that this "return of the Real" in American Psycho goes even deeper than revealing the shift to a consumerist reality. That is, allegorical-didactic Patrick/American Psycho reveals the Real violence of consumerism, a violence we all partake in everyday: murder; misogyny and objectification of/violence against women; lack of empathy; a consumerist (lack of/loss of) identity and singular desire to consume, and the alienation and despair that comes from this ontological mode of being; consumption of others to satisfy needs and appetites; a consumerist identity that doesn't see its own self degradation and is cognitively (hedonistically, narcissistically) detached from mapping its own place in the social order. And this, then, is also the "truth" (Real) of a global capitalism that seems to be inexorably driving us to a de-evolutionary mode of being. In other words, as I've conveyed throughout my essay, like the professor whose Real "framing" is "murderer," allegorical Patrick codes us all as: "American psycho."

I want to end this essay on one final moment in the film. At one point, Patrick encounters "Al," an African American homeless man. Patrick stops and belittles the homeless man. The homeless man does not ask anything from Patrick, an important point. Instead of making the homeless man the stereotypical image of disgust and irrelevance, the man is given a humanity the rest of the highbrow characters lack. Set against the dehumanized, consumerist Patrick, the homeless bum becomes a more "authentic" person. The homeless man's responses to Patrick's entreaties further emphasize Patrick's de-humanized state. For Patrick, the homeless man is merely an object to prop his dented image back up (as I convey above, previous to this moment, Patrick's self-worth takes a bruising when his virtually identical "business card" is deemed inferior to his associates'). He "kills" (consumes) him and Patrick's egomaniacal, narcissistic-consumerist self is reaffirmed.

Allegorically configured in this moment, again, is the clear demarcation between corporate power and proletariat, racial/ethnic Other and the inevitable results of this dichotomy. Others populate almost all low positions in American Psycho accentuating the white, patriarchal power structure so tangibly manifested in the 1980s and to a slightly lesser extent still maintained today. Of all the moments where we see this dichotomy, this moment between Patrick and the African American homeless man is the most telling. After Patrick has given the man a false impression of being human and helping the man (conveying canned lines that echo his earlier "concerned" rhetoric), Patrick stands up and says "I don't have anything in common with you" (shot at a low angle) emphasizing not only Patrick's inhumaneness and utter lack of empathy but also (again, allegorically speaking) a whole upper class of people's sense of superiority and entitlement. In this way, American Psycho cogently shows us the dementia of a capitalistic system. That is, as I suggested earlier in the Jean/misogynist drawings moment - that embedded in consumerism is a violence to self and Other - here too we get this allegorically and didactically spelled out. In typical exchanges between server 
and served in the film, we get at best indifference to the server/Other though typically verbal abuse. However, with this Al moment (and other moments, e.g. the "Christie" moments), we see the Real embedded violence to the Other, whether that be from individuals (e.g., Patrick) or from the film's allegorical counterpart, consumerism and transnational late capitalistic corporate power. In creating this complex allegorical frame of a dominant social and ideological system that simulates class and race "equality" and care for the poor and disenfranchised, American Psycho "maps" out the Real: The Other is mere fodder for the privileged who see these human beings not as human beings but as disposable objects to be consumed for their own ends and needs, their incessant consumerism (wealth accumulation, never-ending drive for profit) an un-empathetic normative state of being, a historical mode of being that is perhaps best - most stunningly - summed up in a moment in Sally Potter's brilliant Orlando (1992): Several aristocrats are looking down on - laughing at - the frozen body of a servant, a young man or woman who apparently fell through the iced over waterway. The moment is telling for its unbelievably utter callousness and cruelty issuing forth in the form of laughter from the privileged royalty. But more than that, the moment speaks to this "frozen" moment in time: In that historical moment (mid to late 16th Century England), royalty could laugh openly at the "low" without recriminations from public backlash, registering the extreme disregard for those below them (as the servant literally is in this scene). Today, such callousness would not be tolerated, at least openly, but that doesn't mean that this utter lack of feeling for the underprivileged are still not "frozen" in place, as this moment between corporate/high Patrick and disposable/low Al testifies to.

It is such moments of (didactic) clarity that offer spectators a way back to a congruent re-intact chain of signifiers. Indeed, coming back to Jameson's theoretical conception "cognitive mapping," Jameson offers us a possible way to remedy our postmodern late capitalistic "psychic fragmentation," a text that (re)situates us in our late capitalistic, globalized, consumerism mode of being; or, rather, curatively, a text that didactically (re) grounds us in a historical-cultural (diachronic) mode of being. In other words, as late capitalistic modes of displacement (consumerism, globalization) continue to phenomenologically dis-locate us from our place in an intelligible economic and ideological structure that determines us, we desperately need texts that "cognitively" re-connect us to our place in the dominant social order. That is why I think "popular" films such as allegorical-didactic American Psycho are so important for they offer us clarity to our reified dehumanized lives, in this case a consumerism and corporate power that serially annihilates women and the self, and that is an invaluable point of departure to engaging our fall into the consumerist "abyss" of lost signifier Patrick Bateman.

\section{Endnotes}

1. See my essay "Allegorical Figurations and the Political Didactic in Bulworth" (2004) in Cineaction 65: 54-61.

2. For interesting and compelling defenses of the book see the following: Elizabeth Young, "The Beast in the Jungle, The Figure in the Carpet: Brett Easton Ellis's American Psycho," Shopping in Space: Essays on American "Blank Generation" Fiction (London: Serpent's Tail, 1992), 85-122; Patrick W. Shaw, "Hubert Selby, Jr.'s Last Exit to Brooklyn and Bret Easton Ellis's American Psycho," The Modern American Novel of Violence (New York: The Whitson Publishing Company, 2000) 187-199; Philip L. Simpson, Psycho Paths: Tracking the Serial Killer Through Contemporary American Film and Fiction (Carbondale: Southern Illinois University Press, 2000), 148-155; Marco Abel, "Judgment is Not an Exit: Toward an Affective Criticism of Violence with American Psycho," Angelaki: Journal of the Theoretical Humanities, 6, no. 3 (December 2001): 140; Linda S. Kauffman, Bad Girls and Sick Boys: Fantasies in Contemporary Art and Culture (Berkeley: University of California Press, 1998), 243-256; Larry
Juchartz and Erica Hunter, "Ultraviolent Metaphors for (Un)Popular Culture: A Defense of Bret Easton Ellis," Popular Culture Review 7.1 (February 1996):6779; Carla Freccero, "Historical Violence, Censorship, and the Serial Killer: The Case of American Psycho," Diacritics 27.2 (1997): 44-58; Michelle Warner, "The Development of the Psycho-Social Cannibal in the Fiction of Bret Easton Ellis," Journal of Evolutionary Psychology 17.2 (March 1996): 140-146; Laura E. Tanner, "American Psycho and the American Psyche: Reading the Forbidden Text," Intimate Violence: Reading Rape and Torture in Twentieth-Century Fiction (Bloomington: Indiana University Press, 1994), 96-114; and David W. Price, "Bakhtinian Prosaics, Grotesque Realism, and the Question of the Carnivalesque in Bret Easton Ellis's American Psycho," Southern Humanities Review 32, no. 4 (Fall 1998): 321334.

3. See David Robinson (2006) "The Unattainable Narrative: Identity, Consumerism and the Slasher Film in Mary Harron's American Psycho" in Cineaction 68: 
26-35 for an interesting reading on the metanarrative angle of the film.

4. I think it is pretty clear that probably most (all?) of the murders are not real. For one, it is clear that Patrick is fantasizing because his fantasy (consumerism) reality breaks down towards the end of the film: A bank machine tells him to "feed" it the cat and we see him go on a preposterous killing spree afterwards (including the implausible shots that blow up two police cars). But I think it is clear before this series of incidences that Patrick is creating an elaborate consumerism "reality." There are many improbable events that speak to daydreaming moments: Patrick dragging Paul Allen's body across the lobby, leaving a trail of blood behind; Patrick taking over Paul Allen's apartment and piling numerous bodies into it (and then we find it clean and empty the day after we see this development); and Patrick chasing Christie, the prostitute, with a whirring chainsaw (again, recalling Leatherface) through an apartment building, Christie screaming and pounding on doors (which nobody answers), until he kills her by improbably aiming and dropping the chainsaw from about five stories up. We also see this breakdown of his fantasy reality in the apparent psychotic comments he makes to other characters. The point has been made that the characters he speaks to are simply so shallow and caught up in their own self-centered consumerism reality that they don't pay attention to him. I think though that it is clear by one scene in particular that it is
Patrick's consumerist "reality." In the dry cleaning shop scene, he seemingly says to the dry cleaning lady, "If you don't shut your fucking mouth, I will kill you," the dry cleaning lady apparently hearing him, her reaction registering shock. However, if the scene is looked at closely, we can hear the conversation between the dry cleaning lady and Patrick continuing under the cutin shot of Patrick screaming his psychotic line. It is interesting to note that if all of these lurid comments are part of Patrick's consumerist "reality," he only fantasizes the laundry lady registering his comments, thus in effect inserting class distinctions into the mix.

5. Les Miserables was a recurring motif in the novel, but we only see the poster this one time in the film. Larry Juchartz's reading of this significant motif sums up its importance in both novel and film: "The author's concern shows as he provides a recurring backdrop in many of his outdoor scenes: buses, park benches, and billboards advertising the Broadway production of Les Miserables - a constant reminder of human misery surrounded by so much human excess." Larry Juchartz and Erica Hunter (1996) "Ultraviolent Metaphors for (Un)Popular Culture: A Defense of Bret Easton Ellis," Popular Culture Review 7.1 (February): 73. In the film, the image perhaps takes another turn. The reflection of Patrick's visage superimposed over Cosette also suggests perhaps a mirror reflection of the miserable (dehumanized) state they both share.

\section{References}

Abel, Marco. 2001. "Judgment is Not an Exit: Toward an Affective Criticism of Violence with American Psycho," Angelaki: Journal of the Theoretical Humanities, 6 (3 December): 137-154.

Arendt, Hannah. 1958. The Human Condition. Chicago: University of Chicago Press.

Caputi, Jane. 1993. "American Psychos: The Serial Killer in Contemporary Fiction," Journal of American Culture, 16 (Winter): 101-112.

Csikszentmihalyi, Mihaly. 2003. "Materialism and the Evolution of Consciousness," Psychology and Consumer Culture: The Struggle for a Good Life in a Materialistic World, eds. Tim Kasser and Allen D. Kanner. Washington DC: American Psychological Association.

Daly, Glyn. 2016. “Slavoj Žižek: Risking the Impossible.” Slavoj Žižek: A Primer. http://www.lacan.com/zizek-primer.htm. Accessed January 15, 2016.

Dexter, Frank. 1992. "Seriality Kills," Here \& Now: A Magazine for Radical Ideas, 12: 29-32.
Hardt, Michael and Antonio Negri. 2000. Empire. Cambridge: Harvard University Press.

Jameson, Fredric. 1977. Afterword in Aesthetics and Politics, trans. Ronald Taylor. London: Verso Publishing.

Jameson, Fredric. 1991. Postmodernism: Or, The Cultural Logic of Late Capitalism. Durham: Duke University Press.

Juchartz, Larry and Erica Hunter. 1996. "Ultraviolent Metaphors for (Un)Popular Culture: A Defense of Bret Easton Ellis," Popular Culture Review, 7.1 (February): 67-79.

Kanner, Allen D. and Renée G. Soule. 2003. "Globalization, Corporate Culture, and Freedom," Psychology and Consumer Culture: The Struggle for a Good Life in a Materialistic World, eds. Tim Kasser and Allen D. Kanner. Washington DC: American Psychological Association.

Kasser, Tim. 2002. The High Price of Materialism. Cambridge: MIT Press.

Rosenberg, Erika L. 2003. "Mindfulness and Consumerism," in Psychology and Consumer Culture: The Struggle for a Good 
Life in a Materialistic World, eds. Tim Kasser and Allen D. Kanner. Washington DC: American Psychological Association.

Tanner, Laura E. 1994. "American Psycho and the American Psyche: Reading the Forbidden Text," Intimate Violence: Reading Rape and Torture in Twentieth-Century Fiction. Bloomington: Indiana University.

Warner, Michelle. 1996. "The Development of the PsychoSocial Cannibal in the Fiction of Bret Easton Ellis," Journal of Evolutionary Psychology, 17.2 (March): 140-146.

Wegner, Phillip E. 2009. Life Between Two Deaths, 1989-2001: U.S. Culture in the Long Nineties. Durham: Duke University Press.

Wilson, Scott. 2000. "SchizoCapital and the Branding of American Psychosis," Cultural Values, 4 (October): 474-496.
Wood, Robin. 1985. "An Introduction to the American Horror Film," Movies and Methods, vol. 2, ed. Bill Nichols. Berkeley: University of California Press.

Wood, Kelsey. 2012. Žižek: A Reader's Guide. Malden, MA: Wiley-Blackwell.

Young, Elizabeth. 1992. "The Beast in the Jungle, The Figure in the Carpet: Brett Easton Ellis's American Psycho," Shopping in Space: Essays on American "Blank Generation" Fiction. London: Serpent's Tail.

Žižek, Slavoj. 1995. Looking Awry: An Introduction to Jacques Lacan through Popular Culture. Cambridge: The MIT Press. 